\title{
The Power of the International Court of Justice to Indicate Provisional Measures to Prevent the Aggravation of a Dispute
}

\author{
PAOLO PALCHETTI*
}

\begin{abstract}
The article aims at examining, in the light of the practice of the International Court of Justice, some issues concerning the power of the Court to indicate provisional measures to prevent the aggravation or extension of a dispute. While the existence of a power to indicate nonaggravation measures appears to be well established in the Court's case law, the scope of this power has proved to be a more controversial issue. This study argues that, by attaching relevance to the element of aggravation, the Court has been able to indicate measures that are not strictly needed to prevent a risk of irreparable harm but which at any rate contribute to a greater protection of the rights of the parties; at the same time, however, the Court has so far refrained from regarding the risk of aggravation as a circumstance which may justify a less stringent evaluation of the other conditions that normally need to be satisfied for the granting of interim protection under Article 4I of the ICJ Statute.
\end{abstract}

\section{Key words}

conditions for granting provisional measures; International Court of Justice; legal effects of provisional measures; prevention of a dispute

\section{INTRODUCTION: AGGRAVATION OF A DISPUTE AS A BASIS FOR GRANTING PROVISIONAL MEASURES}

Under Article 4I of the Statute of the International Court of Justice (the Court), the Court has the power to indicate provisional measures in order 'to preserve the respective rights of either party'. The emphasis laid by this provision on the preservation of rights clearly suggests that the primary purpose of the Court's power to indicate provisional measures is - to use the words of the Court - 'to prevent irreparable prejudice to the rights that are the subject of the dispute'. ${ }^{\mathrm{I}}$ In fact, however, the Court has also made use of its power under Article 4I for a different purpose, considering itself to be entitled to indicate measures aimed at preventing the aggravation or the extension of the dispute. While the existence of a power to indicate non-aggravation measures appears to be well established in the Court's case law, the scope of this power has proved to be a more controversial issue.

\footnotetext{
* Associate Professor of International Law, University of Macerata.

I See Pulp Mills on the River Uruguay (Argentina v. Uruguay), Provisional Measures, Order of I3 July 2006, para. 62 (not yet published).
} 
Non-aggravation measures were first indicated by the Permanent Court of International Justice in its Order of 5 December 1939 rendered in the Electricity Company of Sofia and Bulgaria case. The Permanent Court included in the operative part of its Order a measure directing Bulgaria, inter alia, to 'ensure that no step of any kind is taken capable ... of aggravating or extending the dispute submitted to the Court'.2 The Order did not offer a clear explanation as to the reasons which led the Court to indicate a measure of this kind, ${ }^{3}$ nor did the Permanent Court clarify whether it considered the power to indicate non-aggravation measures as merely ancillary to the power to indicate measures aimed at preventing irreparable prejudice to the rights of the parties.

In its early case law the present Court had frequently indicated non-aggravation measures. In many cases the Court had inserted in the operative parts of its orders granting provisional measures an indication to the effect that the parties should 'ensure that no action of any kind is taken which might aggravate or extend the dispute submitted to the Court'. ${ }^{4}$ Yet indications of this kind appeared to be standard clauses which merely complemented more specific measures. Among the circumstances which came into play in order to justify the decision of granting interim protection, the Court's orders did not refer to the issue of the aggravation of the dispute. The main focus was on the preservation of the rights sub judice. ${ }^{5}$ Accordingly, the indication of provisional measures was generally conditional on specific requirements, namely urgency and the risk of irreparable damage to the rights at issue in the main case. In the Aegean Sea Continental Shelf case the question was raised whether the Court has the power to indicate provisional measures for the sole purpose of preventing the aggravation or extension of a dispute; however, the Court did not find it necessary to examine this issue, since it excluded the possibility that in that case there was an actual risk of aggravation of the dispute. ${ }^{6}$

A clear reference to the Court's power to indicate provisional measures to prevent the aggravation of the dispute is contained in the Order of Io January I986, rendered by the Chamber of the International Court of Justice formed to deal with the case concerning the Frontier Dispute (Burkina Faso/Republic of Mali). In that case, which related to a dispute over the delimitation of the boundary, both parties requested the indication of provisional measures because of certain armed actions in the disputed area. In a much quoted statement, the Chamber held that

2 Electricity Company of Sofia and Bulgaria (Belgium v. Bulgaria), Request for the Indication of Provisional Measures, Order of 5 December I939, PCIJ Rep. (Series A/B) No. 79, at I99.

3 On the possible reasons which led the Permanent Court to adopt this solution see J. Sztucki, Interim Measures in the Hague Court (1983), 76-7.

4 See, for instance, Anglo-Iranian Oil Co. Case (United Kingdom v. Iran), Provisional Measures, Order of 5 July I95I, [I95I] ICJ Rep. 89, at 93; Fisheries Jurisdiction (United Kingdom of Great Britain and Northern Ireland $v$. Iceland), Interim Protection, Order of I7 August I972, [1972] ICJ Rep. I2, at I7; Nuclear Tests (Australia v. France), Interim Protection, Order of 22 June I973, [I973] ICJ Rep. 99, at Io6. For a review of the Court's practice, see S. Oda, 'Provisional Measures', in V. Lowe and M. Fitzmaurice (eds.), Fifty Years of the International Court of Justice. Essays in Honour of Sir Robert Jennings (I996), 54I, at 552-3.

5 See Sztucki, supra note 3, at $74 \mathrm{ff}$.

6 Aegean Sea Continental Shelf(Greece v. Turkey), Interim Protection, Order of I I September I976, [I976] ICJ Rep. 3 , at I3, para. 42 . 
independently of the requests submitted by the Parties for the indication of provisional measures, the Court or, accordingly, the chamber possesses by virtue of Article 4I of the Statute the power to indicate provisional measures with a view to preventing the aggravation or extension of the dispute whenever it considers that circumstances so require. ${ }^{7}$

While, as we shall see, different views have been held as to the actual meaning of this statement, the fact remains that such an explicit recognition of the power of the Court to take non-aggravation measures was novel. ${ }^{8}$ The Chamber's intention was clearly to stress the importance of the issue of aggravation of a dispute as a circumstance which might warrant the indication of provisional measures. This aspect also emerges from other points of the Chamber's Order. In particular, the manner in which the operative part of the Order was structured is significant in this respect. The first measure indicated was one directing both parties not to take any action of any kind which might aggravate or extend the dispute. As noted by one author, 'this suggests that the containment of the dispute was perhaps seen as a matter of priority in this case'. ${ }^{9}$ The Chamber then indicated more specific measures concerning the preservation of evidence, the observance of a ceasefire, the withdrawal of the armed forces of either party, and the administration of the disputed areas.

The approach followed by the Chamber was subsequently endorsed by the Court. In the case concerning Land and Maritime Boundary between Cameroon and Nigeria, the Court was confronted with a situation which had many similarities with that in the Frontier Dispute case. The dispute concerned, inter alia, the delimitation of the territorial boundary between the two states. Following armed actions in the disputed areas, provisional measures were requested by both parties. In its Order of I 5 March I996, the Court recognized that

independently of the requests for the indication of provisional measures submitted by the Parties to preserve specific rights, the Court possesses by virtue of Article 4I of the Statute the power to indicate provisional measures with a view to preventing the aggravation or extension of the dispute whenever it considers that circumstances so require. ${ }^{\text {I0 }}$

The same statement was repeated by the Court in its Order of I July 2000 rendered in the case concerning Armed Activities on the Territory of the Congo. ${ }^{\text {II }}$

It might be argued that the point made by the Court (or by the Chamber) in the above-mentioned statements was mainly directed at emphasizing the fact that the Court is empowered to indicate, proprio motu, provisional measures which are

7 Frontier Dispute (Burkina Faso/Republic of Mali), Provisional Measures, Order of Io January I986, [I986] ICJ Rep. 3, at 9, para. I8.

8 In the same vein, J. Sztucki, 'Case Concerning Land and Maritime Boundary (Cameroon v. Nigeria): Provisional Measures, Order of I5 March I996', (I997) Io LJIL 34I, at 35I.

9 J.G. Merrils, 'Interim Measures of Protection in the Recent Jurisprudence of the International Court of Justice', (I995) 44 ICLQ 90, at I 23.

Io Land and Maritime Boundary between Cameroon and Nigeria (Cameroon v. Nigeria), Provisional Measures, Order of I 5 March I996, [I 996] ICJ Rep. I3, at 22, para. 4I.

I I Armed Activities on the Territory of the Congo (DRC v. Uganda), Provisional Measures, Order of I July 2000, [2000] ICJ Rep. I I I, at I 28 , para. 44 . 
different from those requested by the parties. ${ }^{12}$ However, these statements also lend themselves to a different interpretation. It may be said that the intention of the Court was to convey the idea that, under Article 4I of the Statute, it possesses a power to indicate non-aggravation measures which is 'independent' of the power to indicate measures preserving the rights of either party against irreparable prejudice. 'Independence' in this regard would have a double meaning. This power would be 'independent' in the sense that the indication of non-aggravation measures would not be subject to the same conditions which are normally required when interim protection is sought in order to preserve the rights at issue in a dispute. But it would also mean that the Court would be entitled to indicate non-aggravation measures for the sole purpose of preventing the aggravation of a dispute, even if no measures preserving the rights of the parties are indicated.

The latter interpretation of the Court's (and Chamber's) case law has found some support both within the Court and in the legal literature. Thus, for instance, referring to the above-mentioned statement in the Frontier Dispute case, Judge Bedjaoui, whoit is interesting to note - was the president of the chamber dealing with that case, ${ }^{\mathrm{I} 3}$ observed that the Chamber's Order inaugurated 'a case law which, instead of focusing on a review of each prerequisite to the indication of provisional measures, gives pride of place to a comprehensive analysis of the "circumstances" of the case'; ${ }^{\mathrm{I} 4}$ he also infers from the Chamber's dictum that the indication of provisional measures 'in the general terms of an exhortation to all the parties not to aggravate or extend the dispute ... does not in any way depend upon the indication of other, more specific provisional measures'. ${ }^{5}$ In the same vein, Thirlway, commenting on the statement of the Court in the Land and Maritime Boundary between Cameroon and Nigeria case, observed that 'what is clearly meant is that the power to indicate non-aggravation measures exists whether or not preservative measures are indicated' ${ }^{\mathrm{I} 6}$

However, a recent decision of the Court seems, at least in part, to contradict this reading of the Court's prior case law. In its Order of 23 January 2007, rendered in the case concerning Pulp Mills on the River Uruguay, ${ }^{17}$ the Court retained a narrow view as to the scope of its power to indicate provisional measures to prevent the aggravation of a dispute. As we shall see later, the Court refused to indicate a general

I2 See K. Oellers-Frahm, 'Article 4I', in A. Zimmermann, C. Tomuschat, and K. Oellers-Frahm (eds.), The Statute of the International Court of Justice: A Commentary (2006), 923, at 932.

I3 The Chamber was composed of Judges Bedjaoui (president), Lachs, and Ruda, and of Judges ad hoc Luchaire and Abi-Saab. Judge Lachs had also advocated a more active role for the Court in contributing to the peaceful settlement of disputes. In his Separate Opinion attached to the Order of I I September I 976 in the Aegean Sea Continental Shelf case, he criticized the Court, arguing that it should have put greater stress on 'the need for restraint on the part of both States and the possible consequences of any deterioration or extension of the conflict'. Aegean Sea Continental Shelf, supra note 6, at 20. However, Judge Lachs was not suggesting that the Court should indicate provisional measures; he was arguing that the Court should make recommendations to the parties. On the distinction between provisional measures and recommendation, see infra, section 5 .

I4 Aerial Incident at Lockerbie (Libyan Arab Jamahirya v. United States of America), Provisional Measures, Order of I4 April I996, [I996] ICJ Rep. I43, at I 58, para. 32 (Judge Bedjaoui, Dissenting Opinion).

I5 Ibid.

i6 H. Thirlway, 'The Law and Procedure of the International Court of Justice I960-I989. Part Twelve', (200I) 72 British Year Book of International Law 37, at I03. Contra Sztucki, supra note 8, at 351.

I 7 Pulp Mills on the River Uruguay (Argentina v. Uruguay), Provisional Measures, Order of 23 January 2007 (not yet published), paras. 49-50. The author of this article wishes to acknowledge that he acted as advisor for Uruguay in the proceedings. 
measure directing the parties not to aggravate or to extend the dispute, arguing that in its previous case law it had only indicated a measure of this kind when more specific measures had also been indicated.

The purpose of the present study is to examine, in the light of the Court's practice, some issues concerning the power of the Court to indicate provisional measures to prevent the aggravation or extension of the dispute. No doubt, by placing emphasis on the issue of aggravation the Court has taken a broad view as to the scope of its power under Article 4I. However, it remains to be seen to what extent the Court has actually relied on the risk of aggravation as a basis for granting provisional measures. This study argues that, by attaching relevance to the element of aggravation, the Court has been able to indicate measures that are not strictly needed to prevent a risk of irreparable harm but which at any rate contribute to a greater protection of the rights of the parties; at the same time, however, the Court has refrained so far from regarding the risk of aggravation as a circumstance which may justify a less stringent evaluation of the other conditions that normally need to be satisfied for the granting of interim protection under Article 4I. In the light of this consideration, it is not believed that the recent decision in the Pulp Mills case is inconsistent with the position taken by the Court in its previous case law. This does not mean that the explicit recognition by the Court of the limits of its power to indicate nonaggravation measures does not constitute a significant novelty, whose reasons and implications deserve to be further explored.

The study is structured as follows. Section 2 will attempt to define the notion of aggravation of the dispute with a view both to clarifying better the distinction between non-aggravation measures and measures preserving specific rights, and to assessing whether, in the Court's view, a risk of aggravation of the dispute presupposes a situation of threats or actual use of force in the relations between the parties. Section 3 deals with the conditions for the indication of non-aggravation measures; its main purpose is to analyse the views expressed by some authors and by individual judges according to which, when the Court seeks to prevent the aggravation of a dispute, certain conditions which are normally required for the indication of provisional measures do not apply. Section 4 addresses the question of whether the Court is empowered to indicate non-aggravation measures in a case in which measures preserving rights are not indicated; it is in this context that the recent decision in the Pulp Mills case will be examined. Section 5 is dedicated to the question concerning the content and legal effects of the measures that the Court may indicate to prevent the aggravation of a dispute. In the final paragraphs the main conclusions of the study will be recapitulated.

\section{WHAT ARE THE CIRCUMSTANCES WHICH MAY JUSTIFY THE INDICATION OF NON-AGGRAVATION MEASURES?}

Article 4I of the Statute provides that the Court has the power to indicate provisional measures if 'circumstances so require'. The urgency and the risk of irreparable prejudice to the rights that are the subject of the dispute have generally been regarded by the Court as the main circumstances that may justify the grant of provisional 
measures. However, when reference is made to the power to indicate non-aggravation measures, relevance is given to a different circumstance, namely the risk of an aggravation of the dispute. The notion of aggravation seems to include a broader category of conduct than that covered by the notion of irreparable harm. While conduct giving rise to irreparable harm also results in an aggravation of the dispute, the opposite does not necessarily hold true. ${ }^{18}$ Thus the main difference between non-aggravation measures and other preventive measures seems to lie in the fact that only the latter type of measure presupposes the existence of an urgent need to prevent irreparable harm to the rights in dispute, while non-aggravation measures are related to actions which, by aggravating the dispute, create a risk more generally of prejudice to the rights of the parties. ${ }^{\text {I9 }}$

The Court has not given explicit indications as to the test to be applied in order to determine whether the risk of aggravation is such as to require the grant of interim protection. It must be appreciated in the light of the particular circumstances of each case whether there is a risk of an aggravation. At first glance, a restrictive view of the notion of aggravation appears to have been adopted by the Chamber dealing with the Frontier Dispute case. In the above-mentioned Order of I 986 , the recognition of the power to indicate non-aggravation measures was immediately followed by the consideration that, in situations which

comprise a resort to force which is irreconcilable with the principle of the peaceful settlement of international disputes, there can be no doubt of the Chamber's power and duty to indicate, if need be, such provisional measures as may conduce to the due administration of justice. ${ }^{20}$

The link thus established between the Court's power to indicate non-aggravation measures and situations which 'comprise a resort to force' may be taken as implying that, in the Chamber's view, the use of such power must be limited to situations involving a threat of force or even an actual use of force.

To be sure, the indication of non-aggravation measures is particularly warranted in situations involving the risk of a military escalation. However, this does not seem to be the only circumstance in which these measures may be ordered. There is little support for such a restrictive view in the Court's case law prior to the Chamber's Order, as the Court had indicated non-aggravation measures even in cases where there was no question of the use of force. ${ }^{2 \mathrm{I}}$ Nor does it seem that the Court has endorsed the Chamber's view in its subsequent case law. It is true that the other two cases in which the Court expressly referred to its 'independent' power to indicate non-aggravation measures - the Land and Maritime Boundary between Cameroon and Nigeria case and the case concerning Armed Activities on the Territory of

I8 Sztucki, supra note 3, at 74 .

I9 Referring to the above-mentioned measure indicated by the Permanent Court in the Electricity Company of Sofia and Bulgaria case, Hersch Lauterpacht significantly observed that, following that decision, 'the possible irreparability of the damage ceased to be the decisive criterion applied by the Court'. H. Lauterpacht, The Development of International Law by the International Court of Justice (I958), 253.

20 Frontier Dispute case, supra note 7, at 9, para. I9.

2I Perhaps the clearest example in this respect is the Court's Order of 22 June I973 rendered in the case concerning the Nuclear Tests, supra note 4. 
the Congo - both related to situations involving the use of military force. ${ }^{22}$ However, in these cases the Court refrained from expressly linking the power to indicate non-aggravation measures to situations involving the use of force. In particular, the statement contained in paragraph I9 of the Chamber's Order was not repeated in the Court's two subsequent Orders. Moreover, it is significant that the Court has sometimes taken into consideration the possibility of indicating non-aggravation measures in situations where it was clear from the outset that there was no risk of a military escalation. In Criminal Proceedings in France, for instance, the Court contemplated the possibility of using this power in relation to a situation where there was no question of the use of force. Its refusal to grant such measures was not grounded on the fact that there was no risk of a military escalation. The Court simply found that, under the circumstances of the case, there did not appear to be 'any need for measures of this kind to be indicated'. ${ }^{23}$

It serves little purpose to link the power to indicate non-aggravation measures to the risk of a military conflict. First, as we shall see, the establishment of such a link could not guarantee that the Court would grant interim protection in every such situation, given that its power is, in any event, dependent on the existence of a prima facie basis of jurisdiction. ${ }^{24}$ Furthermore, there are no evident reasons why the Court should limit the use of its 'independent' power to indicate non-aggravation measures to cases where there is a risk of military confrontation. An aggravation or extension of the dispute may be caused by actions that, without involving the threat or use of force, may have similar negative effects on the relations between the parties.

It is interesting to note that, in the first case in which the risk of an aggravation of the dispute was taken into account in the context of a request for provisional measures, a broad meaning was given to the notion of aggravation. In its Order of 5 December 1939, rendered in the Electricity Company of Sofia and Bulgaria case, the Permanent Court of International Justice recognized that states that were parties to a dispute before it had a duty not to aggravate this dispute. It spoke of a principle universally accepted to the effect that the parties to a case must 'not allow any step of any kind to be taken which might aggravate or extend the dispute'. ${ }^{25}$ This wide reference to 'steps of any kind which might aggravate or extend the dispute' seemed to imply that, in the Court's view, the notion of aggravation was not restricted to

22 This circumstance is reflected in the formula employed by the Court in the operative part of its orders. The first measure indicated in the Order rendered in the Land and Maritime Boundary between Cameroon and Nigeria reads as follows: 'Both parties should ensure that no action of any kind, and particularly no action by their armed forces, is taken ... which might aggravate or extend the dispute before it'. Supra note io, at 24. In the Armed Activities on the Territory of the Congo case, the Court indicated a measure directing the parties to 'prevent and refrain from any action, and in particular any armed action, ... which might aggravate or extend the dispute before the Court or make it more difficult to resolve'. Supra note I I, at I29. It may be observed that the formula employed by the Court in both cases, referring to action of any kind, 'particularly' armed action, seems to imply a recognition that actions other than armed action might also risk aggravating the dispute.

23 Criminal Proceedings in France (Republic of the Congo v. France), Provisional Measures, Order of I7 June 2003, [2003] ICJ Rep. I02, at I I6, para. 39.

24 On this point, see Thirlway, supra note I6, at Io2.

25 Electricity Company of Sofia and Bulgaria, supra note 2, at I 99. 
acts of a military nature. Whatever opinion one may have about the precise relation between the infringement by the parties of their duties as litigants before the Court and the indication of provisional measures, ${ }^{26}$ it seems reasonable to argue that the view expressed by the Permanent Court suggests that the range of acts which might aggravate a dispute is not limited to those involving the use of force.

\section{CONDITIONS FOR THE INDICATION OF NON-AGGRAVATION MEASURES: THE COURT'S JURISDICTION TO DEAL WITH THE DISPUTE AND THE LINK BETWEEN THE MEASURES REQUESTED AND THE MAIN DISPUTE SUBMITTED BY THE PARTIES}

When a request for provisional measures is filed with a view to preserving specific rights, the Court has to be satisfied, inter alia, that it has prima facie jurisdiction with regard to the merits of the case and that the rights sought to be preserved by the requested provisional measures are the same rights which constitute the subject matter of the main dispute. ${ }^{27}$ One may ask whether the same conditions apply in relation to the Court's power to indicate provisional measures with a view to preventing the aggravation or extension of a dispute. It may be maintained that these conditions are strictly related to the idea that provisional measures are a means directed primarily towards preserving the rights at issue in a case and that they do not necessarily apply when the Court seeks to prevent the aggravation of a dispute.

A radical view has sometimes been expressed by individual judges to the effect that, when confronted with situations involving the use of force, the Court has the power to indicate provisional measures directed at preventing the aggravation of a dispute regardless of whether the Court has prima facie jurisdiction to deal with that dispute. This view is mainly premised on the idea that the Court, as the principal judicial organ of the United Nations, has an important role to play in the maintenance of international peace. This role of the Court would justify, inter alia, a less stringent application of the conditions that generally apply for the indication of provisional measures in cases involving the threat or the actual use of force. ${ }^{28}$

The view described above was apparently advocated by some judges in their dissenting opinions attached to the Court's Orders of 2 June I 999 in the Legality of

26 On this point, see Sztucki, supra note 3, at $79 \mathrm{ff}$. The existence of a connection between the Court's power to indicate non-aggravation measures and the parties' duty not to interfere with or obstruct proceedings pending before the Court by coercive extrajudicial means was recently advocated by Judge Buergenthal in his declaration annexed to the Court's Order of 23 January 2007 in the case concerning Pulp Mills on the River Uruguay.

27 For an examination of the Court's practice in this respect see S. Rosenne, 'Provisional Measures and Prima Facie Jurisdiction Revisited', in N. Ando, E. McWhinney, and R. Wolfrum, Liber Amicorum Judge Shigeru Oda (2002), I, 5 I 4; C. Dominicé, 'La compétence prima facie de la Cour internationale de Justice aux fins d'indication de mesures conservatoires', ibid., 383; Oellers-Frahm, supra note I2, at 934.

28 Referring to the views sometimes held by individual members of the Court, one author has raised the question whether a special regime for provisional measures in cases involving the use of force is emerging. See C. Gray, 'The Use and Abuse of the International Court of Justice: Cases Concerning the Use of Force after Nicaragua', (2003) I4 EJIL 867, at $888 \mathrm{ff}$. On the Court's power to indicate provisional measures in situations involving the use of force, see also R. Ranjeva, 'La prescription par la Cour internationale de Justice de mesures conservatoire à portée militaire', in E. Yapko and T. Boumedra (eds.), Liber Amicorum - Mohammed Bedjaoui (I 999), 449. 
the Use of Force cases. In these cases, the Federal Republic of Yugoslavia had requested the Court to indicate provisional measures directing the respondent states to cease their armed action in Kosovo. The Court refused to grant interim protection, arguing that it lacked prima facie jurisdiction to do so; in its Orders, however, it inserted a statement calling on the parties to respect their obligations under international law and not to aggravate or extend their dispute. ${ }^{29}$ Some judges criticized this decision, contending that, despite the lack of prima facie jurisdiction, the Court would have been entitled to indicate provisional measures. This was the position taken by Judge Weeramantry, who clearly stated, 'I feel the Court should have gone further than it has done and issued provisional measures on the lines indicated'. ${ }^{30}$ In his view, the Court had jurisdiction, inter alia, 'to direct both parties to take all measures necessary to prevent an aggravation of the situation and for the restoration and maintenance of international peace and security in the region'. ${ }^{\text {I }}$ Judges Shi and Vereshchetin took a more nuanced position. Judge Vereshchetin stated that

even if ultimately the Court may come to the conclusion that, due to constraints in its Statute, it cannot indicate fully-fledged provisional measures in accordance with Article 4I of the Statute in relation to one or another of the respondent States, the Court is inherently empowered, at the very least, immediately to call upon the Parties neither to aggravate nor to extend the conflict and to act in accordance with their obligations under the Charter of the United Nations. ${ }^{32}$

Similarly, Judge Shi said that

the Court would have been fully justified in point of law if, immediately upon receipt of the request by the Applicant for the indication of provisional measures, and regardless of what might be its conclusion on prima facie jurisdiction pending its final decision, it had issued a general statement appealing to the Parties to act in compliance with their obligations under the Charter of the United Nations and all other rules of international law relevant to the situation, including international humanitarian law, and at least not to aggravate or extend their dispute. ${ }^{33}$

It is not clear what kind of measures, in the view of Judges Shi and Vereshchetin, the Court should have taken - whether it should have been a simple recommendation to the parties or a provisional measure under Article 4I. Since the Court's Orders did in fact contain in its reasons a general statement recommending that the parties avoid aggravating the dispute, it seems reasonable to hold that what they had in mind was the indication of a provisional measure. ${ }^{34}$

Whatever the views expressed by these judges, the fact remains that the Court has never taken into consideration the possibility of indicating non-aggravation measures in the absence of a basis for prima facie jurisdiction. While this point has not been explicitly dealt with by the Court, it has to be noted that in all the cases

\footnotetext{
29 Legality of the Use of Force (Yugoslavia v. Belgium), Provisional Measures, Order of 2 June I999, [I999] ICJ Rep. I 24 , at I 40 , para. 49.

30 Ibid., at 203.

3 I Ibid., at 202.

32 Ibid., at 209.

33 Ibid., at 207.

34 In the same vein see Gray, supra note 28 , at 889 .
} 
in which the Court indicated non-aggravation measures, a finding of prima facie jurisdiction was invariably regarded as a necessary precondition for granting interim protection. When it found that it lacked prima facie jurisdiction, it refrained from indicating any provisional measures, without inquiring whether such measures were warranted in the light of the risk of an aggravation of the dispute. In such cases the only 'relief' that the Court was disposed to grant was to insert in its reasoning a statement recommending to the parties that they respect their obligations under international law and refrain from aggravating or extending the dispute. ${ }^{35}$ Since statements of this kind are not included in the operative part of the Court's orders, they cannot be regarded as equivalent to provisional measures. I will revert to this question later. ${ }^{36}$

While the position of the Court on the issue of jurisdiction is hardly surprising and does not seem to deserve comment, a more complex problem concerns the requirement that provisional measures relate to the main claims which constitute the subject matter of the dispute. It is not self-evident why non-aggravation measures, based as they are on the need to ensure the containment of a dispute, should be strictly limited to protecting the rights of the parties at issue in the case. Thus the view has been expressed that non-aggravation measures, with their emphasis on the restraint of escalation,

are by definition unrelated to the nature of the rights claimed, except by the tenuous link that the actions that are to be enjoined must presumably be actions that might aggravate the dispute over those rights, not actions that might generally impair good relations between the parties. ${ }^{37}$

An even stronger view has been advanced by one author, who argued that, when the Court seeks to prevent the aggravation of a dispute, it is empowered to protect rights other than those already at issue in the case, provided that there is an instrument which confers on the Court prima facie jurisdiction to deal with those rights. ${ }^{38}$

It seems doubtful that the Court is entitled to grant interim protection to rights which are not at issue in the main case. In that regard, it is not enough for the Court to be able, in principle, to rely on an instrument granting jurisdiction over those rights. It is for the parties to delimit the object of the dispute over which the Court is called upon to exercise its jurisdiction. The Court does not have the power to protect proprio motu rights of the parties that are not in dispute in the case before it;

35 Apart from the Orders of 2 June 1999 in the Legality of Use of Force cases, see also Armed Activities on the Territory of the Congo (New Application: 2002) (Democratic Republic of the Congo v. Rwanda), Provisional Measures, Order of Io July 2002, [2002] ICJ Rep. 2 I 9, at 249-50, para. 93.

36 Infra section 4.

37 Thirlway, supra note I6, at I06. According to this author, since non-aggravation measures do not strictly relate to the rights in dispute in a case, it would be difficult to see how the jurisdiction to indicate measures of this kind 'can be an element of the jurisdiction to entertain the merits'. Ibid., at 85 .

38 In this sense see D. W. Greig, 'The Balancing of Interests and the Granting of Interim Protection by the International Court', (I99I) I I Australian Year Book of International Law I08, at I 27. According to Greig, 'there would seem to be no logical reason against the granting of interim measures to prevent an extension of the dispute to encompass other rights appertaining to the litigants'; to this end, 'an appropriate test might be to limit the Court's competence under Article $4 \mathrm{I}$ by reference to the question of whether the rights sought to be protected also fell, prima facie at least, within its jurisdiction on the merits'. 
this would constitute an ultra petita. Moreover, as interim protection is granted by virtue of an incidental jurisdiction, it does not seem that a party could be allowed to extend the subject of the dispute through a request for provisional measures aimed at protecting rights which, until that moment, were not at issue in the case. If a party wishes to obtain interim protection of a right which is not at issue in the dispute pending before the Court but which may be infringed by the conduct of the other party, and if that party may rely on a valid jurisdictional basis, it may always decide to submit a new application and request the Court to indicate provisional measures relating to those rights.

Even in those cases where great significance was accorded to the need to prevent the aggravation of a dispute, the Court was careful to stress that the measures requested were strictly linked to the main dispute submitted by the parties. Thus, for instance, in the Frontier Dispute case, the Chamber referred to the fact that the armed actions that gave rise to the requests for the indication of provisional measures submitted to the Chamber took place within or near the disputed area as defined by the Special Agreement'. ${ }^{39}$ Similarly, in its Order of I5 March I 996 in the case concerning Land and Maritime Boundary between Cameroon and Nigeria, the Court remarked that 'armed actions regrettably occurred on territory which is the subject of proceedings before the Court'. ${ }^{\circ}$ Both statements were clearly directed at linking the need to prevent the military escalation in the disputed area with the subject of the main dispute, thereby suggesting that, by preventing the aggravation of the dispute, the Court was also helping to preserve the rights at issue in the main case. In the Order of 8 April I 993 rendered in the Application of the Convention on the Prevention and Punishment of the Crime of Genocide (Bosnia and Herzegovina v. Yugoslavia (Serbia and Montenegro)), the link between the non-aggravation measure indicated to the parties and the subject of the main dispute was clearly reflected in the formula employed in the operative part of that Order, which runs as follows:

The Government of the Federal Republic of Yugoslavia (Serbia and Montenegro) and the Government of the Republic of Bosnia and Herzegovina should not take any action and should ensure that no action is taken which may aggravate or extend the existing dispute over the prevention or punishment of the crime of genocide, or render it more difficult of solution. ${ }^{4}$

The Court's adherence to the principle that interim protection must relate to the rights at issue in the case is also shown by the fact that, in all cases in which it had indicated non-aggravation measures, the Court did not take into account only the element of aggravation. Even in those cases where it placed particular emphasis on that element, the Court maintained that the facts giving rise to the aggravation also created a risk of irreparable damage to the rights of the parties at issue in the case. Thus, in its Order in the Land and Maritime Boundary case, the Court first

39 Frontier Dispute case, supra note 7, at 9, para. I6.

40 Land and Maritime Boundary between Cameroon and Nigeria, supra note io, at 22, para. 39.

4I Application of the Convention on the Prevention and Punishment of the Crime of Genocide (Bosnia and Herzegovina v. Yugoslavia (Serbia and Montenegro), Provisional Measures, Order of 8 April i993, [I993] ICJ Rep. 3, at 24, para. 52. 
considered that 'the rights at issue in these proceedings are sovereign rights which the Parties claim over territory', adding that 'these rights also concern persons'; ${ }^{2}$ it then observed that 'the events that have given rise to the request, and more especially the killing of persons, have caused irreparable damage to the rights that the Parties may have over the Peninsula'.43 Quite apart from the question of whether it is right to assume that the killing of persons falls within the subject matter of a dispute concerning a question of sovereignty over a territory - a point which prompted some reactions even within the Court itself ${ }^{44}$ - it should be noted that, by referring to the risk of irreparable damage to the rights at issue, the Court showed that the focus of its intervention was mainly related to the protection of the rights at issue in the case, and not the protection of rights falling outside the subject matter of the dispute.

Thus the Court's practice reveals that the element of aggravation must in any case be linked with the protection of the rights of the parties which are at issue in a case. This conclusion, which conforms to the idea underlying Article 4I of the Statute that the function of interim measures is to protect the rights of the parties at issue in a case, should not be taken as implying that no differences exist between measures preserving the rights of the parties from irreparable damage and non-aggravation measures. As we have seen in section 2, the notion of aggravation of the dispute covers a wider category of actions than the notion of irreparable prejudice. However, the fact that non-aggravation measures are not strictly needed to prevent a risk of irreparable prejudice does not mean that they are not related to the protection of the rights at issue in the case. As noted by one author, 'the possible aggravation or extension of the dispute is a circumstance in which measures could be given but the measures must, in all cases, be aimed at preserving the rights of the parties'. ${ }^{45}$

\section{THE RELATIONSHIP BETWEEN NON-AGGRAVATION MEASURES AND MEASURES AIMED AT PRESERVING SPECIFIC RIGHTS}

Since the notion of aggravation of the dispute is broader than the notion of irreparable harm, the situation may arise where a party takes action which risks aggravating the dispute but which is not such as to cause an imminent risk of irreparable harm to the rights of the other party. One may wonder whether, in such situations, the Court would be prepared to exercise its power under Article 4I solely for the purpose of preventing the aggravation of a dispute.

42 Land and Maritime Boundary between Cameroon and Nigeria, supra note 10, at 22, para. 39.

43 Ibid., at 23, para. 42. See also the Court's Order of I July 2000 in the case concerning Armed Activities on the Territory of the Congo, supra note I I, at I 25, para. 43.

44 In his declaration annexed to the Court's Order, Judge Oda remarked that 'loss of life in the disputed area, distressing as it undoubtedly is, does not constitute the real subject matter of the dispute'. Land and Maritime Boundary between Cameroon and Nigeria, supra note Io, at 26-7, para. 2. On this point see also Thirlway, supra note I6, at 98; Y. Iwamoto, 'The Protection of Human Life through Provisional Measures Indicated by the International Court of Justice', (2002) I5 LJIL 345.

45 J. B. Elkind, Interim Protection: A Functional Approach (I98I), at 228. For a similar view see also Merrils, supra note 9, at I23; L. Daniele, Le misure cautelari nel processo dinanzi alla Corte internazionale di giustizia (I993), at 9 I. 
As has already been observed, the Court's case law prior to the recent decision in the Pulp Mills case did not provide a clear answer to this question. By admitting, as it did in its Order in the Land and Maritime Boundary between Cameroon and Nigeria case, that, under Article 4I, it possesses the power to indicate non-aggravation measures 'independently of the requests for the indication of provisional measures submitted by the Parties to preserve specific rights', the Court had given credence to the view that the indication of provisional measures in order only to prevent the aggravation of the dispute was to be regarded as admissible. As a matter of fact, however, the Court had never based the indication of provisional measures solely on the need to prevent the aggravation of the dispute. Admittedly, in some cases, the main focus was on the issue of aggravation. Yet, as we have seen, in conjunction with that issue the Court always referred also to the existence of a risk of irreparable harm to rights which constituted the subject of the dispute. Thus without excluding the possibility of indicating non-aggravation measures in cases in which no measures preserving rights are indicated, the Court refrained from availing itself of this possibility, preferring instead to rely also on the need to prevent irreparable harm to the rights of the parties.

The Court's approach could be explained by the fact that, when the circumstances of a case might involve an imminent risk of irreparable harm, the Court would also find it appropriate to refer to that element, as this would provide a more reassuring basis for granting provisional measures. Indeed, as noted by Judge Buergenthal in his declaration appended to the Order of 23 January 2007 in the Pulp Mills case, the fact that the Court had not had occasion to indicate non-aggravation measures in a case in which measures preserving rights had not also been indicated 'does not necessarily prove that it lacks the power to do so'. ${ }^{46}$ In the same Order, however, the Court took a different position. Uruguay had requested the Court to indicate three different provisional measures, the first being a specific measure directing Argentina to take all steps at its disposal to prevent or end the interruption of transit between Uruguay and Argentina, the other two being general measures directing Argentina to abstain from any measures which might aggravate the dispute and to refrain from any other measure that might prejudice the rights of Uruguay at issue in the case. The Court refused to grant the first measure because it found that there was no risk of irreparable prejudice to the rights of Uruguay at issue in the case. ${ }^{47}$ With regard to the second measure requested by Uruguay, the Court noted that, in all cases in which it issued provisional measures directing the parties not to take any conduct which would aggravate or extend the dispute, other measures were also indicated; thus it found that since it had not upheld the first provisional measure requested by Uruguay it could not indicate the other measure requested by that state to the effect that Argentina should abstain from any measure that might aggravate or extend the

46 Pulp Mills on the River Uruguay (Argentina v. Uruguay), supra note I 7, para. 8 (Judge Buergenthal, Declaration). 47 Ibid., para. 4I. 
dispute. ${ }^{48}$ For the same reasons the Court decided that it could not indicate the third measure requested by Uruguay. ${ }^{49}$

As the Court dealt with this point very concisely, different interpretations can be advanced as to the exact meaning of the Court's reasoning concerning the indication of non-aggravation measures. It may be argued that the Court intended simply to say that it cannot indicate a general measure directing the parties to refrain from conduct aggravating the dispute when the circumstances of a case do not warrant the indication of more specific measures. This interpretation would allow for the possibility that, under certain circumstances, the Court could indicate specific measures aimed at preventing the aggravation of the dispute even when no provisional measures are held to be needed in order to preserve the rights of the parties from an imminent risk of irreparable harm. Yet if one interprets the Court's dictum in the light of the specific context of that case - taking into account, in particular, the fact that the other measure requested was aimed at preserving Uruguay's rights at issue in the case and that the Court had refused to grant such a measure because of the lack of an imminent risk of irreparable harm to Uruguay's rights - a more plausible reading of the Court's Order would suggest that, in the Court's view, non-aggravation measures can be granted only if the circumstances of a case are such as to require the indication of measures aimed at preventing irreparable harm to the rights of the parties. Thus non-aggravation measures would merely be ancillary to measures directed at preserving specific rights.

This reading of the Order is supported also by the views held in this respect by Judge Buergenthal, who found that the Court's findings

are based on the conclusion that the Court lacks the power under Article 4I to indicate any provisional measures in a case in which there has been no showing of an imminent risk of irreparable prejudice to the subject matter in dispute between the parties..$^{\circ}$

In his declaration Judge Buergenthal criticized the Court's 'restrictive interpretation' of Article 4I, arguing that, by taking this position, the Court did not adequately address the problem of how to deal with

situations in which one party to the case resorts to extrajudicial coercive measures, unrelated to the subject matter in dispute, that aggravate a dispute by seeking to undermine or interfere with the rights of the other party in defending its case before the Court. ${ }^{\text {I }}$

While, for the above-mentioned reasons, it cannot be argued that the conclusion reached by the Court in this Order contradicts its previous case law, as Judge Buergenthal seems to suggest,,$^{2}$ it is difficult not to agree with him on the fact that neither

\footnotetext{
Ibid., paras. 49-50.

Ibid., para. 5I.

Buergenthal, supra note 46, para. Io.

Ibid., para. I I.

Ibid. Judge Buergenthal noted that the language employed in Art. 4I permits a less restrictive interpretation than that adopted by the Court, specifying that such an interpretation 'finds expression in the Court's repeated assertions that it "possesses by virtue of Article 4I of the Statute the power to indicate provisional measures with a view to preventing the aggravation or extension of the dispute whenever it considers that circumstances so require”'.
} 
the language of Article 4I nor the previous case law warranted such a conclusion. Indeed, this decision appears to be based on a restrictive interpretation of Article 4I. The cautious approach followed by the Court in this case is the more remarkable because, as pointed out by several commentators, ${ }^{53}$ since the Chamber's statement in the Frontier Dispute case the Court's case law appeared to be characterized by a tendency towards attaching ever more relevance to the issue of aggravation. Since the Order of 23 January 2007 does not provide elements which may help to clarify the reasons for the Court's restrictive view, one may only attempt to identify some possible reasons as a matter of conjecture. I shall come back to this point in the next section.

\section{The CONTENT AND LEGAL EFFECTS OF NON-AGGRAVATION MEASURES}

The fact that it is now clear that non-aggravation measures cannot be indicated in the absence of a risk of irreparable damage to the rights of the parties should not lead one to underestimate the possible relevance of the issue of aggravation within the context of the Court's power under Article 4I. Even if the existence of a risk of an aggravation of the dispute does not per se justify the granting of interim protection, such a risk remains one of the circumstances which has to be taken into account when considering what measures are to be indicated in order to protect the rights of the parties. In other words, while attaching decisive importance to the possible risk of irreparable prejudice, the Court is not bound to focus exclusively on this element, but can also consider the broader implications that the actions of one of the parties may have on the dispute before it. This, in turn, reflects on the content of the measures that the Court would be entitled to indicate. In this respect, the element of aggravation plays a significant role in that it seems to widen the margin of appreciation of the Court in determining what measures should be ordered. In particular, the existence of a risk of aggravation of a dispute may justify the indication by the Court of measures that are not strictly needed to prevent the rights of the parties from being irreparably prejudiced. ${ }^{54}$

The point now made is well illustrated by certain cases in which the Court did not merely call on the parties to refrain from aggravating the dispute but also specified the steps that the parties had to take to that end. Thus, as we have seen, in the Order rendered in the Frontier Dispute case the Chamber, in addition to a provisional measure directing the parties to ensure that no action be taken which might aggravate the dispute or prejudice the right of the other party, indicated

53 See Sztucki, supra note 8, at 357 ('It appears that in the recent decades in general, and in the present case in particular, the Court, using Article 4I, is embarking on exercising just these powers - powers of general prevention'); Oda, supra note 4, at 552-3 ('It seems, however, that the Court has become inclined to interpret article 4I of the Statute much more widely so as to cover cases in which the prevention of an aggravation or extension of the dispute is required or even where the status quo needs to be maintained, although it has not indicated provisional measures solely to that end'); Thirlway, supra note I6, at 99 ('Recent developments in the practice of indication of provisional measures suggest that there has been some shift of thinking within the Court away from the intentions of the Statute in this respect').

On this point see Sztucki, supra note 3, at 77. 
more specific measures concerning, inter alia, the respect of a ceasefire agreement and the withdrawal of armed forces from a certain area. 55 Similar measures were indicated by the Court in the Land and Maritime Boundary case. Since in these two cases the existence of a risk of irreparable prejudice was also recognized, it cannot be said that these measures were exclusively aimed at preventing an aggravation of the dispute. ${ }^{56}$ However, it seems that, in shaping the content of some of them, the need to prevent the aggravation of the dispute had a major role. This point was acknowledged explicitly by the Chamber, at least as far as the measure directing the parties to withdraw their troops from the disputed area was concerned:

The measures which the Chamber contemplates indicating, for the purposes of eliminating the risk of any future action likely to aggravate or extend the dispute, must necessarily include the withdrawal of the troops of both Parties to such positions as to avoid the recrudescence of regrettable incidents. ${ }^{57}$

In the great majority of cases, non-aggravation measures have taken the form of a general request that the parties refrain from any action which may aggravate or extend the dispute. Indeed, general measures of this kind have been regarded as standard clauses, as the Court usually included such measures in the operative part of its orders. ${ }^{5}$ Recently, however, general statements recommending that the parties refrain from aggravating the dispute have sometimes been included in the reasons of the orders. This has happened, in particular, in cases in which the Court had found that the conditions for granting provisional measures were not satisfied. In addition to the above-mentioned Orders in the Legality of the Use of Force cases, one may also refer, for instance, to the Orders of I 3 July 2006 and 23 January 2007 in the Pulp Mills case. ${ }^{59}$ With regard to this practice, it can asked what the difference is, if any, between a statement of this kind included in the operative part of an order indicating provisional measures and a similar statement included in the reasons of such order. Are these latter statements also to be considered as an expression of the Court's power, under Article 4I, to indicate non-aggravation measures?

The question now raised is strictly related to a different one, which concerns the legal effects of provisional measures aimed at preventing the aggravation of the dispute. The problem is whether the recognition of the Court in the LaGrand case that provisional measures have binding effects also applies to non-aggravation measures. ${ }^{60}$ If one considers that general statements of this kind do not have binding effect even when they are included in the operative part of a Court's order indicating provisional measures, it would make little difference whether these statements are

55 Suprasection I.

56 For a different view see Thirlway, supra note I6, at 107, who argues that only the measure directing the parties to preserve the status quo as regards the administration of the disputed areas 'could be regarded as a true preservative provisional measure'.

57 Frontier Dispute case, supra note 7, at IO-I I, para. 27.

58 See Sztucki, supra note 3, at 77, who observed that the function of these general clauses appeared to be that of reinforcing other measures that the Court could decide to indicate.

59 Pulp Mills on the River Uruguay (Argentina v. Uruguay), respectively supra note I, para. 82, and supra note I7, para. 53.

60 LaGrand (Germany v. United States of America), Merits, Judgment of 27 June 200I, [200I] ICJ Rep. 466, at 506, para. Iog. 
included in the operative part or in the reasons of an order: in each case they would be no more than recommendations made by the Court with no binding effects on the parties.

However, there seems to be little doubt that, when included in the operative part of an order, non-aggravation measures have binding effect on the parties. ${ }^{6 \mathrm{I}} \mathrm{In}$ its judgment rendered in the LaGrand case, the Court referred explicitly to nonaggravation measures. When indicating the reasons which pointed to the binding character of provisional measures, it noted that 'measures designed to avoid aggravating or extending disputes have frequently been indicated by the Court', adding that these measures 'were indicated for the purpose of being implemented'.$^{62}$ Furthermore, in all cases subsequent to the LaGrand judgment, in which the question of the compliance with orders indicating provisional measures was raised, the Court has never distinguished between non-aggravation measures and measures preserving rights, considering both kinds of measures as having binding effect. ${ }^{63}$ Most recently, in its judgment of 26 February 2007 in the Application of the Convention on the Prevention and Punishment of the Crime of Genocide (Bosnia and Herzegovina v. Serbia and Montenegro) case, the Court noted that 'the Court's order of 8 April and I3 September I993 indicating provisional measures created legal obligations which both Parties were required to satisfy'; ${ }^{64}$ among the measures having binding effect referred to by the Court, the above-mentioned measure indicating that the parties were not to aggravate the dispute was also explicitly included.

The difference between statements calling on the parties not to aggravate the dispute which are contained in the operative part of an order and similar statements included in the reasons is therefore clear: only the former statements may be considered to be provisional measures and, as such, to have binding effect on the parties. Statements included in the reasons are to be considered simply as recommendations addressed to the parties. ${ }^{65}$ Obviously, the latter type of statement is not subject to the same conditions as provisional measures. In fact, the Court often resorts to such recommendations when the conditions for granting interim protection are not satisfied.

Although the difference between non-aggravation measures and statements included in the reasons is easy to detect, it is more problematic to establish whether there is a connection between the recognition of the binding effect of provisional measures and the Court's recent practice on matters concerning the aggravation of a dispute. As regards the tendency to include in the reasons a statement calling on the parties not to aggravate the dispute, it has been suggested that a connection could indeed exist: since it is now clear that only statements included in the operative part

\footnotetext{
6I Similarly, see Thirlway, supra note i6, at I07.

62 LaGrand (Germany v. United States of America), supra note 60, at 503, para. 103.

63 See Land and Maritime Boundary between Cameroon and Nigeria (Cameroon v. Nigeria: Equatorial Guinea intervening), Merits, Judgment of Io October 2002, [2002] ICJ Rep. 303, at 453, para. 321; Armed Activities on the Territory of the Congo (DRC v. Uganda), Merits, Judgment of I 8 December 2005, para. 262 (not yet published).

64 Application of the Convention on the Prevention and Punishment of the Crime of Genocide (Bosnia and Herzegovina $v$. Serbia and Montenegro), Merits, Judgment of 26 February 2007, para. 452 (not yet published).

65 In the same sense, J. D’Aspremont, 'The Recommendations Made by the International Court of Justice', (2007) 56 ICLQ I 85 , at I $87-8$.
} 
can be considered as provisional measures having binding effect, it would be easier for the Court to include such general statements in its reasons. ${ }^{66}$ For the purposes of the present study, however, far more relevant is the question of whether there is a link between the position recently taken by the Court in its Order of 23 January 2007 and the novelty introduced with the LaGrand judgment. It is here submitted that also in this respect a connection could be found to exist. Two different, albeit related, arguments can be advanced in this regard.

First, it may be argued that the recognition of the binding effects of provisional measures has led the Court to take a more cautious approach in administering its power under Article 4I. Since, as we have seen, the notion of aggravation of a dispute covers a wider category of actions than that of irreparable prejudice, a request for nonaggravation measures may be designed to obtain from the Court interim protection in cases in which there is only a tenuous link between the rights at issue in the case and the actions to be enjoined. By specifying that non-aggravation measures cannot be rendered in a case in which there is no risk of irreparable prejudice to the rights of the parties at issue in a case, the Court might have wanted to stress the fact that its intervention under Article 4I aims primarily at the preservation of such rights, thus dispelling any doubts as to the possibility that, by taking into account the need to prevent the aggravation of the dispute, the Court would be entitled to extend its binding power to indicate provisional measures on matters which are unrelated or only tenuously related to that over which it has jurisdiction.

The second argument moves from the consideration of the content of the nonaggravation measure that the Court was requested to indicate in the Pulp Mills case. In its Order of 23 January 2007 the Court said that it could not grant provisional measures consisting solely of an injunction directing the parties not to take any actions which could aggravate or extend the dispute. It is submitted that the Court's refusal to indicate a measure having the form of a general request to the parties not to aggravate the dispute could be a consequence of the new context created after the Court's judgment in the LaGrand case.

When the Court does not specify what actions one or both parties should take in order to prevent the aggravation of the dispute, the question may arise as to the possible implications flowing from this general measure. In the absence of specific indications, parties may have different views as to what conduct would constitute an infringement of such a measure. Prior to the Court's judgment in the LaGrand case, this problem did not attract much attention in the Court's practice. In the Hostages case, the Court mentioned the fact that the incursion into the territory of Iran by the United States was contrary to a previous Court Order indicating that no action was to be taken by either party which might aggravate the tension between the two countries. Yet in that case the Court made only a cursory reference to this issue. ${ }^{67}$

66 For this observation see T. Treves, 'The Political Use of Unilateral Applications and Provisional Measures Proceedings', in J. A. Frowein, K. Scharioth, I. Winkelmann, and R. Wolfrum (eds.), Verhandeln für den Frieden - Negotiating for Peace. Liber Amicorum Tono Eitel (2003), 463, at 479.

67 United States Diplomatic and Consular Staff in Tehran (United States of America v. Iran), Merits, Judgment of 24 May I980, [I980] ICJ Rep. 3, at 43, para. 93. For an examination of the Court's position in this case, see S. Rosenne, The Law and Practice of the International Court I 920-I 996 (I 997), III, at I I 49-50. 
The scant attention given at that time to the question concerning the parties' compliance with provisional measures is not surprising if one considers that, untilits judgment in the LaGrand case, the Court had not taken a position on whether or not provisional measures are binding on the parties. ${ }^{68}$ Now that the Court has clarified that provisional measures are binding, the issue of compliance with such measures is going to arise more frequently in the Court's practice. Parties are now fully entitled to request the Court to rule that the other party has violated its international obligation to comply with a provisional measure and can even submit a claim for reparation. In fact, recent practice shows that, when the relevant conditions arise, parties have included in their final submissions a request concerning the issue of compliance with provisional measures. ${ }^{69}$

Thus, in the new context created after the Court's judgment in the LaGrand case, the question of whether conduct gives rise to an aggravation of the dispute is likely to become a more important issue for litigant states. When formulated in general terms, non-aggravation measures could be used by a party as a ground for advancing far-reaching claims as to the steps that the other party has to take in order to comply with such measures. While it will be for the Court to decide whether such claims are justified in the light of the measures previously indicated, and while, in any case, a party can decide to submit a new request for provisional measures, it seems that, under certain circumstances, non-aggravation measures framed in general terms may generate a state of uncertainty in the relations between the parties and may therefore give rise to a further dispute. ${ }^{70}$ This may help to explain why the Court has refused to grant provisional measures consisting solely of a general statement relating to the need to prevent the aggravation of the dispute. While the Order of 23 January 2007 does not exclude the possibility that the Court may indicate general measures of this kind when other, more specific, measures are also indicated, it may be thought, for the reasons explained above, that, even in such a case, the Court may tend to avoid including non-aggravation measures formulated in general terms in the operative part of its orders.

\section{Conclusions}

Since the explicit recognition in the I986 Frontier Dispute Order that under Article 4I the Court has an 'independent' power to indicate measures to prevent the aggravation or extension of the dispute, different views have been taken as to the scope of this Court's power. It has been argued, not least by individual judges, that the need to prevent the escalation of a dispute, particularly in cases involving a threat or actual

68 For an analysis of the Court's practice prior to the judgment in the LaGrand case, see Oellers-Frahm, supra note I 2, at 954-5; P. Gaeta, La giustizia cautelare nel diritto internazionale (2000), at I47.

69 See the Judgments referred to supra notes 63 and 64.

70 In this respect see the remarks made by Judge Eiriksson in his dissenting opinion annexed to the Order of 27 August 1999 rendered by the International Tribunal of the Law for the Sea in the Southern Bluefin Tuna case. He contested the decision of the Tribunal to indicate a measure - which was binding on the parties 'of so general a nature that a party cannot be entirely clear when contemplating any given action whether or not it falls within its scope'. The text of Judge Eiriksson's opinion is available at the Tribunal's website (http//www.itlos.org). 
use of force, could justify a less stringent application of the conditions generally applied for the indication of provisional measures; the view has also been advanced by some that the Court is entitled to indicate non-aggravation measures in cases in which measures preserving the rights of the parties are not indicated.

These views, which are based on an extensive interpretation of Article 4I, do not find support in the Court's practice. Admittedly, in some cases the indication of provisional measures appeared to have been motivated mainly by the need to prevent an aggravation of the dispute. It is true, moreover, that by relying on the element of aggravation, the Court considered itself to be entitled to indicate measures which appeared to go beyond what was strictly needed in order to prevent irreparable prejudice to the rights at issue in the case. Nevertheless, non-aggravation measures have been indicated only when the Court has found that all the conditions which normally must be satisfied for the indication of provisional measures, including the existence of a risk of irreparable prejudice to the rights of the parties, were satisfied.

While in its previous case law the Court had never indicated non-aggravation measures in cases where measures preserving rights were not also indicated, it is only in its recent Order in the Pulp Mills case that the Court has explicitly ruled out the possibility that it had the power to do so. The clear limitation imposed by the Court on its power to indicate non-aggravation measures is a significant novelty. It has been argued that there could be a link between this new development and the recent recognition, made in the LaGrand judgment, that provisional measures are binding. 